Tina Božiković, mag. praesc. educ.

Faculty of Humanities and Social Sciences Alumna, University of Split

Department of Pre-school Education

tbozikovic@ffst.hr

Ina Reić Ercegovac, PhD, Associate Professor

Faculty of Humanities and Social Sciences, University of Split

Chair of Psychology

inareic@ffst.hr

Katija Kalebić Jakupčević, PhD, spec. clin. psych.

Faculty of Humanities and Social Sciences, University of Split

Chair of Psychology

kkalebicjakupcevic@ffst.hr

\title{
THE CONTRIBUTION OF TEMPERAMENT AND PARENTAL BEHAVIOUR TO THE DEVELOPMENTAL OUTCOMES OF PRESCHOOL CHILDREN
}

\begin{abstract}
Summary: The aim of this study was to examine whether the dimensions of parental behavioural style contribute to the explanation of the developmental characteristics of preschool children beyond children's temperamental characteristics. A total of 194 parents of one preschool child, of which $95.36 \%$ were mother, participated in the study. The EASI temperament survey, the Multidimensional Assessment of Parenting Scale and the Preschool Child Development Assessment Questionnaire were used. The results suggested a significant correlation between the dimensions of temperament according to the EASI model (emotionality, activity, sociability and impulsivity), the functional developmental characteristics of the child and some dimensions of parenting. No significant differences were found in the assessments of temperamental characteristics and developmental outcomes between boys and girls. The results of regression analyses showed that temperamental dimensions assessments explained significant portion of preschool children developmental outcomes variance (between $56 \%$ and $74 \%$ ). Furthermore, with temperamental characteristics being controlled for, the dimensions of parental behaviour did not significantly increase portion of explained criteria variance. In addition to the limitations of the study, the results were discussed in the context of existing knowledge on the developmental outcomes of preschool children with special emphasis on the importance of recognizing and understanding temperament as an important determinant of development in early ages.
\end{abstract}

Keywords: developmental characteristics, parental behaviour, preschool-aged child, temperament 


\section{INTRODUCTION}

Temperament represents the specifics of each child and determines the child's emotional expressiveness and willingness to respond to environmental stimuli. Certain dimensions of temperament partially influence the upbringing of a child, i.e. the dynamics of parental behaviour and environmental response. Children are born with a certain temperament and biologically conditioned traits. Since the child's personality still does not include numerous components which become visible later, such as beliefs, values and attitudes, its study is limited to studying the expression of emotions and reactions to environmental stimuli, i.e. temperament. Vasta et al. (1997) define temperament as a set of behavioural dispositions which make the specific way a person expresses their emotions and moods and describes the child's behavioural style and answers how a child does something, not reflecting what it does.

According to Rothbart et al. (Rothbart \& Derryberry, 1981; Rothbart \& Putnam, 2002) the components of a child's temperament in early and preschool age shape the child's personality, highlighting as the most important: positive emotionality (smiling in response to various pleasant stimuli, excitement and enjoyment), negative emotionality (dissatisfaction, frustration, failure) and effortful control (inhibition, planned behaviour, shifting and focusing attention) (Starc et al., 2004). Tatalović et al. (2017) link temperament to a combination of dynamic constructions and learning processes and is, just as the dynamic system of various factors, delicate to the effect of participants who manifest various personality traits and contextual conditions. Similarly, Brezinšćak and Roje (2018) state how heritage does not determine the child's entire personality, but a large part of the characteristics which later develop under the influence of the environment, mostly parents.

Stating parents' experiences, Pernar (2010) considered the myth where the child's nature is irrelevant, as well as his inborn temperament and other features to be inaccurate. The author explains how there is an agreement among parents and experts regarding the fact that some children are born with an exceptionally difficult temperament, while others are very easy and cooperative. It is clear that such dispositions determine the children's upbringing, the reactions of the surrounding and the parental dynamics which ultimately leads to individual differences in personality traits and behaviour of each child and individual.

According to Starc et al. (2004) a child with an easy temperament shows positive emotions and long persistence, is less easily scared and possesses a moderate level of activity. Such a child offers the parent a feeling of parental competence and warm emotional attachment. A child with a difficult temperament shows few positive emotions with a smile, has a short persistence, is scared easily, has a low level of activity, and leaves the parents feeling not very competent resulting in feelings of fear, tension and big responsibility. A child of slow-to-warm up temperament 
needs time to adjust to changes and is mostly of negative emotionality. But, just as the parents shapes the child, the child also shapes the parent. Sindik and BastaFrljić (2008) conclude that parents can help the child understand their temperament, i.e. how it affects their feelings and behaviour. In this context it is worth noting, according to Pernar (2010), that in correcting the child's behaviour parents should only comment on a specific behaviour they disagree with, and not the child's entire personality because it is detrimental to the overall experience of oneself. Also, educators and parents should understand the child's temperament and adjust their own reactions accordingly, keeping in mind that their behaviour and attitude affects their children's growth and development.

The theoretical frame for this research is the model of temperament developed by Buss and Plomin $(1975,1984)$. It is a developmental, multidimensional EASI model according to which the temperament includes four basic dimensions - emotionality, activity, sociability and impulsivity. In later versions of the model the dimension of impulsivity was left out because it did not get the empirical confirmation considering stability and hereditability. Emotionality refers to the intensity and the quality of emotional reactions, i.e. it points to how quickly a child becomes excited and starts to react negatively to environmental stimuli. At the start of life, emotionality can be estimated by the speed of reaction to, for example, a sound stimulus followed by a manifestation of unpleasant emotions like crying. During the first year of life, emotionality is developed according to reactions of fear and anger and depends greatly on the child's experience. Activity represents the way a child uses energy, and includes tempo, intensive reactions, endurance and motivation. Children rated high on this dimension are constantly in motion and are focused on exploring new places and activities. Sociability refers to the children's preference to socialization and spending time with other people, and those rated high on this dimension do not like being alone and often encourage interaction with others (Vasta et al., 1997).

\section{PARENTING}

Parenting is a term which refers to an entire series of processes happening within a specific time and space. Klarin (2006) states that the complexity of the influence of the surrounding, danger and insecurity in everyday life make the parent's role ever more complex. And while researchers mostly focused on studying the influence of the mother on the child, contemporary literature points to the fact that an even distribution of parental duties has a positive experience of parenting in both parents (Buljan Flander \& Ćorić Špoljar, 2018). Moreover, the same authors emphasize that the contemporary view on parenting and upbringing is a mutual process between parents and children. Ljubetić et al. (2019) state parents as the children's first teachers who direct them in their emotional and social development and emphasize how parents have the most important role in the children's 
development and with their actions affect their cognitive, psychological, physical, social, emotional and moral development. Šimić and Ljubetić (2018) emphasize the effect of positive psychological adjustment of parents to their new role which increases the overall self-confidence and the feeling of attachment to the child. Also, quality parenting, within a stable family structure, is key for maintaining the function and structure of the family and is also key for maintaining a wholesome and healthy development of all individuals within a family community, as well as the society as a whole (Ljubetić \& Batinica, 2015). And while searching for satisfying answers in parenting, parents choose different parenting philosophies, Ljubetić (2011) states how some parents turn to religion, some to their own intuition, while others recall their parents' behaviour and try to change it and/or adjust it.

Parenting style represents an overall mood, climate in which various interactions between parents and children take place. There are several types of parenting styles, one of the most common is defined by Diana Baumrind (1967) which conduces that parental monitoring, love and warmth are the most important elements of parental role. Accordingly, she defined four parenting styles: authoritarian, authoritative, permissive and uninvolved (Obradović \& Čudina-Obradović, 2003, p. 269). Parental warmth refers to support, caring and encouraging the child, while parental control is characterized by the parent's desire to manage their child's life, control their behaviour with punishments, showing power and deprivation (Klarin, 2006). The second classification of parenting style is offered by Rohner's parenting model (1986) based on a dimensional approach where the key dimension is parental acceptance with parental rejection and acceptance on the other end. At the base of this model Rohner (1986) tried to predict the consequences of parental rejection and acceptance on the child's behaviour, their cognitive and emotional developmental and the overall functioning at an adult age. Namely, considering the presence or absence of parental warmth or acceptance, this author defines two types of parents. One type of parents accepts the child, physically and verbally supports it, while the other rejects it thus showing animosity and anger towards it. Accordingly, Klarin (2006) emphasizes that children who perceive the parent relationship as rejecting show predominantly aggressive behaviour and animosity towards others. In any case, it is completely clear that parental warmth and support are favorable in the child's upbringing, whereas rejection and ignoring are unfavorable and as such can have negative consequences on the child's development.

Within the integrative parenting model which consists of subjective experience of parenting, parental behaviour, actions and parenting style, Obradović and Čudina-Obradović (2003) state the following influences on parenting: parent characteristics (personality and gender, emotional maturity, psychological healthy, knowledge, etc.), child characteristics (gender, age, temperament, ability, etc.) and a wider social and family context (family structure, economic safety, marital support, etc.). Namely, each child brings out in a caregiver reaction in line with 
the parents' perception and the child's temperament. The degree of coincidence of the parental influence on the upbringing and the children's temperament implies creating an educational surrounding which accepts the children's behaviour while at the same time encourages a more adaptive functioning (Berk, 2008). Also, children's characteristics contribute to the ease with which the parents can apply the authoritative parenting style. Therefore, impulsive and emotionally negative children will probably provoke violent and inconsistent disciplining (Berk, 2015).

Bowlby (1988, according to Reić Ercegovac and Ljubetić, 2019) explains how attachment from early childhood, on the basis of which an individual creates inner working models, shapes the parenting style, which emphasizes that safe attachment plays an important role in the inter-generational transfer of the parenting experience and behaviour. The same authors emphasize the importance of a focused mindful parenting which stems from an intentional focusing of attention on a current parent-child interaction, without judging. Parents who are trying to identify the child's current needs and accept them, can create a supporting educational context thus creating a quality interaction and more satisfaction with the child. Dimensions referring to the child, as the authors explain it, include attention focused on a current event, empathy and child acceptance. Ljubetić (2011) sees mindful parenting as the ultimate goal, i.e. an imperative of responsible parenting at the core of which parents take full responsibility in order to raise a healthy, intelligent and happy child.

Parenting competence represents a continuum from pedagogical incompetence to pedagogical competence which includes functional and dysfunctional upbringing (Ljubetić, 2012). The author claims that "pedagogically competent parent has to, on a daily basis" and multiple times, "activate all the components of their parenting meta-competence for they are otherwise unable to successfully meet their parental role" (Ljubetić, 2012, p. 26).

According to Obradović and Čudina-Obradović (2003) the parenting experience and the feeling of parenting competence has a significant effect on the children's characteristics. Authors emphasize that newborns and children in their first year of life, along with changing the parenting experience (due to characteristics of their own temperament), also have an effect on creating an emotional climate provoking in parents' behaviours and actions which can positively or negatively affect the child's overall development. Each parents' action contains at its core goals and values defined by developmental results they wish to achieve. How will children accept their parents' activities and actions is determined by the impact of goals and values, and authors define them as context, the surrounding in which the child perceives, interprets and accepts different parent actions. 


\section{CHILD DEVELOPMENT AT EARLY AND PRESCHOOL AGE}

By development we mean a series of changes in characteristics, abilities and child behaviour for which children change and become bigger, more skillful, more competent, more sociable, more adaptable, etc. (Starc et al., 2004). Development is a dynamic process which goes through predictable steps within a social context. Roje and Buljan Flander (2018) emphasize that in order to support development it is essential to follow children, offer them optimal challenges, difficult, but also easy enough to complete independently or with the help of a competent peer, i.e. an adult.

Many authors consider emotional development to be one of the most important processes in the development of personality which at the same time represents the result of mutual influences of biological features of an individual and their social learning (Bašić et al., 2005). Emotional development begins at birth by differentiating comfort and discomfort out of which later, during development, different positive or negative emotions differentiate (Berk, 2008), for example, anxiety, rage, jealousy, disgust and fear, i.e. satisfaction, joy, amazement and affinity to others. Authors emphasize that emotional development in children is the outcome of their needs, very emphasized in early years through physiological, psychological and social needs which children can meet while interacting with people, i.e. their family. What is more, negative emotions will appear less frequently and will lose intensity if positive emotions are nurtured, thus building a positive self-image.

Buljan Flander and Ćorić Špoljar (2018) emphasize the need for little everyday frustrations in order for children to emotionally develop, describing these situations as precious and valuable for learning. Knowing the children's emotional state enables us to understand them, heave realistic expectations and deal with their behaviour more effectively (Brezišćak \& Roje, 2018, p. 48). They also state that children will experience all emotions, but it depends on their temperament what emotions will be more frequent and intense. The process of learning the skills for dealing with emotions is under the influence of the development of the nervous system which, the authors emphasize, offers the basic needs for emotion control, control of the children's temperament and parent support. The important thing is to encourage children to skillfully manage emotions, (i.e. help them find a constructive and acceptable way which is an integral part of emotional self-control) which begins in early childhood, but continues to develop and perfect during most of our lives. Emotional self-control, as one of the most important elements of emotional intelligence, depends on inherited dispositions as well as environmental influences where parents play the key role.

Social development is closely linked to emotional development, and is perceived in adopting social behaviours necessary for adjusting to others and society. From an early age, social interaction acts thorugh hereditary and acquired dispositions and the child in that process isn't passive, but active (Bašić et al., 2005). 
Socially competent children are those who venture into satisfying interactions with adults and other children and through these interactions improve their competence. Numerous factors from the micro-system affect the development of social competences, such as family, peers, educators, teachers, etc. (Katz \& McClellan, 2005). These authors list emotional regulation, social knowledge and understanding, social skills and social dispositions as important components of social competence. They claim that social skills are the most important for social participation and success and that children with developed social competence skills adjust their behaviour to other people's, they exchange information and analyze similarities and differences. Katz and McClellan (2005) also point out the problems of socialization (shyness, low level of interaction, aggressiveness and loneliness) present in children who have not yet achieved a satisfying impulse control or in children who lack the knowledge and skills necessary to enter into peer interactions.

An important aspect of a child's development includes development of motor skills which follows a timeline where the child gradually shows more complex movement abilities (Štimac \& Božić Knež, 2018). Motor skills development is seen in the increasing ability of purposeful and harmonious use of the body which, for a normal psycho-motor development, requires experience (Bašić et al., 2005). Authors emphasize that mental development is very important for motor skills development, considering the fact that curiosity and interest lead children to explore the word surrounding them. Nevertheless, there can be obvious individual differences in the degree and tempo of motor skills development among children of the same age, conditioned by hereditary and environmental factors. Also, improvements in motor skills happen spontaneously, with the maturing of the nervous and musculoskeletal system, and the development of senses and perception. Children need to have as many opportunities to discover their physical surrounding and the joy of movement (Starc et al., 2004).

Cognitive development refers to mental processes by which children try to understand the world around them and it occurs through a gradual mastering of concepts and thinking (Slunjski, 2012). It is of exceptional importance to insure conditions for attention development and cognitive strategies as well as a continuity of experiences. Slunjski (2001) emphasizes the importance of knowing individual needs, affinities and the potentials of the child well and then encouraging and supporting independent learning accordingly. The child's thinking, i.e. cognitive abilities include memory, learning, attention, opinion, problem solving skills, learning and reasoning abilities and decision making (Roje \& Buljan Flander, 2018).

From all of the listed, it is obvious that the child's development is a complex process in which influences of biological inheritance, surrounding, and the child's experiences are combined and direct development. Multiple factors can prove critical in the child's developmental outcomes at a certain developmental stage, so this research aimed to verify if parental behaviour contributes to explaining the 
child's abilities at a certain developmental stage beyond temperamental features which represent the biological dispositions of the child. Namely, although research suggests an important role of parental behaviours for different developmental outcomes of children, such as internalized/externalized difficulties (Parent et al., 2016), research rarely takes into account the specifics of child temperament as a factor on which both parental behaviour and its impact on the child's development depend.

In order to achieve the stated goal, the research attempted to answer the following research questions: (1) Examine the relationship between parents' sociodemographic characteristics and their assessments of parental behaviour; (2) Examine whether there are differences in parental behaviours, parental assessment of the child's temperament, and parental assessment of developmental characteristics with respect to the child's gender; (3) Examine whether the dimensions of parental behaviour contribute to developmental features of the child beyond the dimensions of the child's temperament; (4) Examine whether the dimensions of parental behaviour and temperament contribute to the child's developmental characteristics.

\section{METHOD}

\section{SAMPLE}

An appropriate sample participated in the study, with total of 194 parents of preschool aged children participated in the research, $95.36 \%$ of whom were mothers. Considering the age, the sample included $3.61 \%(\mathrm{~N}=7)$ of parents in the youngest (18-25 years old) and oldest group (over 46 years old), $59.28 \%$ of parents $(\mathrm{N}=115)$ aged $26-35$ and $33.51 \%(\mathrm{~N}=65)$ of parents aged 36-45. As regards their education, the majority consisted of parents with a university degree $(\mathrm{N}=78$, i.e. $40.21 \%$ ), followed by parents with a secondary education $(\mathrm{N}=70$ or $36.08 \%)$ and parents with college degree or a completed bachelor program $(\mathrm{N}=46$, i.e. $23.71 \%)$.

\section{RESEARCH INSTRUMENTS}

The general data questionnaire gathered data on age, gender, and parents' level of education with three closed type questions and data on the child's gender.

The Multidimensional Assessment of Parenting Scale (Parent and Forehand, 2017) was used to measure two parenting domains - positive parenting (four factors: warmth- for example I show love to my child by hugging, kissing or holding him in my arms, support - for example I respect the child's opinion and encourage him to express it, positive reinforcement - for example If I ask a child for something and he does it, I praise him for listening to me and proactive parental behaviour - for example I explain to the child why I am disciplining him for ugly 
behaviour) and negative parenting (three factors: hostility - for example I shout and yell when my child behaves badly, permissiveness - for example I am releasing the child from punishment earlier than I originally said and physical control - for example When I'm extremely angry, I slap my child). The questionnaire was translated from English into Croatian for research purposes by using a standard procedure of a back translation to ensure its comparability with the original (Hui \& Triandis, 1985; Van de Vijver \& Hambleton, 1996). The questionnaire consists of 34 items, and the participants' assignment was to rate how often they behaved in the described way in the last two months on a scale from 1 to $5(1-$ never, 5 - always). Since the reliability coefficients of certain factors indicated a low reliability in two sub scales - warmth and support, a confirmatory factor analysis was carried out on six factors (RMSEA $=07$; chi-squared test $/ \mathrm{df}=2.22$ ). Finally, six composite scores were formed, three for each of two wide domains of parenting (positive/negative) by adding up the answers to items which made each subscale. Descriptive indicators of sub scales are shown in Table 1.

Table 1 Descriptive indicators of parenting behaviour subscales

\begin{tabular}{lcccccc}
\hline & M (SD) & $\begin{array}{l}\text { Number } \\
\text { of items }\end{array}$ & Cronbach $\alpha$ & Range & Skewness & Kurtosis \\
\hline Warmth & $28.50(1.96)$ & 6 & .68 & $20-30$ & -1.56 & 2.33 \\
$\begin{array}{l}\text { Positive } \\
\text { reinforcement }\end{array}$ & $18.81(1.74)$ & 4 & .65 & $12-20$ & -2.00 & 4.26 \\
$\begin{array}{l}\text { Proactive } \\
\text { behaviour }\end{array}$ & $25.34(3.12)$ & 6 & .63 & $16-30$ & -.62 & .07 \\
$\begin{array}{l}\text { Hostility } \\
\text { Permissiveness }\end{array}$ & $14.33(3.48)$ & 7 & .65 & $6-23$ & .21 & -.26 \\
Physical control & $5.70(2.41)$ & 4 & .83 & $4-15$ & 1.59 & 2.04 \\
\hline
\end{tabular}

The EASI temperament survey (Instrument of Child Temperament, Buss and Plomin, 1975, according to Sindik \& Basta Frljić, 2008) was used for the assessment of four dimensions of children's temperament - emotionality (for example Easy to get scared), activity (for example It is constantly on the move), sociability (for example He prefers to play alone than with others) and impulsivity (for example In the game he quickly exchanges toys). The questionnaire applied in this research consisted of 20 items where participants assessed whether the described behaviour applies to their child on a scale from 1 to 5 (1-strongly disagree, 5 - strongly agree). In earlier applications a satisfying reliability of the internal consistency type as well as test retest reliability was established (Matthiesen \& Tambs, 1999; Sindik \& Basta Frljić, 2008). Considering the theoretical model, empirical data and satisfying reliability coefficients, four results have been formed 
as sums of assessments on items which make each individual dimension. It must be pointed out that from emotionality, activity and impulsivity subscales one item was left out, compared to previous research (Sindik \& Basta Frljić, 2008) due to lower reliability. Descriptive indicators of children's temperament sub scales are shown in Table 2.

Table 2 Descriptive indicators of children's temperament subscales

\begin{tabular}{lccccccc}
\hline & $\mathrm{M}$ & $(\mathrm{SD})$ & $\begin{array}{c}\text { Number } \\
\text { of items }\end{array}$ & $\begin{array}{c}\text { Cronbach } \\
\alpha\end{array}$ & Range & Skewness & Kurtosis \\
\hline Emotionality & 10.87 & 3.74 & 4 & .67 & $4-19$ & .02 & -.74 \\
Activity & 12.90 & 3.75 & 4 & .57 & $4-20$ & -.11 & -.66 \\
Sociability & 17.85 & 6.09 & 5 & .88 & $5-25$ & -.67 & -.89 \\
Impulsivity & 11.19 & 3.94 & 4 & .75 & $4-20$ & .13 & -.67 \\
\hline
\end{tabular}

The preschool aged children development questionnaire was used for the assessment of developmental features of children. It consists of 37 questions which relate to different developmetnal areas (speech- for example Exactly retells the story from the picture book, fine motor skills - for example Colors within the default line, cognitive abilities - for example Distinguishes past and future in terms of major events, independence - for example Independent when eating, socio-emotional competence - for example Shows empathy, difficulties - for example Uncontrolled wet). Parents assessed the development of each feature on the assessment scale from 1 to 5 (1-strongly disagree, 5- strongly agree). A high reliabiltiy of all subscales was estalished and results were formed by areas of development shown in Table 3.

Table 3 Descriptive indicators of children's developmental features sub scales

\begin{tabular}{lccccccc}
\hline & $\mathrm{M}$ & $(\mathrm{SD})$ & $\begin{array}{r}\text { Number } \\
\text { of items }\end{array}$ & $\begin{array}{c}\text { Cronbach } \\
\alpha\end{array}$ & Range & Skewness & Kurtosis \\
\hline Speech & 18.71 & $(7.41)$ & 5 & .96 & $5-25$ & -.93 & -.82 \\
Motor skills & 16.82 & $(5.69)$ & 5 & .78 & $5-25$ & -.63 & -.82 \\
$\begin{array}{l}\text { Independence } \\
\begin{array}{l}\text { Cognitive } \\
\text { abilities }\end{array}\end{array}$ & 11.31 & $(4.47)$ & 3 & .96 & $3-15$ & -.93 & -.77 \\
$\begin{array}{l}\text { Socioemotional } \\
\text { competence }\end{array}$ & 17.72 & $(7.08)$ & 5 & .94 & $5-25$ & -.68 & -1.07 \\
$\begin{array}{l}\text { Developmental } \\
\text { difficulties }\end{array}$ & 25.73 & $(9.42)$ & 7 & .95 & $7-35$ & -.86 & -.81 \\
\hline
\end{tabular}




\section{RESEARCH PROCEDURES AND DATA ANALYSIS}

The research was carried out online in May 2020. Parents of preschool children from several preschool institutions in the Split-Dalmatia County participated in the research. In a short guide, they were introduced to the purpose of conducting the research and how to fill out the questionnaire. All participants were stressed that the research is anonymous, that they access it voluntarily and that they are free to withdraw at any time. Since most variables had skewness and kurtosis parameters in the -2 to +2 range, the data analysis used parametric procedures (Gravetter $\&$ Wallnau, 2014), and statistic application STATISTICA 13 was used.

\section{RESULTS}

In order to examine whether there is a relationship between socio-demographic factors of parents and their assessments of parental behaviour, the calculated correlations are shown in Table 4. The results showed a strong relation between the parents' gender, warmth and permissiveness, mothers showing a higher level of warmth as well as a lower level of permissiveness. Age and parents' level of education showed no correlations with the variables of parental behaviour.

Table 4 Relationship between parental behaviour and parents' socio-demographic factors

\begin{tabular}{lccc}
\hline & Gender of the parent & Age of the parent & Level of education \\
\hline Warmth & $.16^{*}$ & .09 & .05 \\
Positive reinforcement & .05 & .01 & .01 \\
$\begin{array}{l}\text { Proactive parental } \\
\text { behaviour }\end{array}$ & $.18^{*}$ & -.07 & .12 \\
Permissiveness & $-.19^{*}$ & .09 & .06 \\
Hostility & -.01 & .07 & .01 \\
Physical control & -.05 & -.10 & -.04 \\
\hline
\end{tabular}

Table 5 shows t-test results which compared parental behaviour with respect to the child's gender. The results showed no differences in the assessment of all variables of parental behaviour with respect to the child's gender. Parents have equally assessed their parental behaviour regardless of whether the child is a boy or a girl. 
T. Božiković, I. Reić Ercegovac, K. Kalebić Jakupčević, The Contribution of ...

Table 5 Parental behaviour with respect to the child's gender

\begin{tabular}{lccccc}
\hline & $\mathrm{M}_{\text {boys }}$ & $\mathrm{M}_{\text {girls }}$ & $\mathrm{SD}_{\text {boys }}$ & $\mathrm{SD}_{\text {girls }}$ & $\mathrm{t}(\mathrm{df}=192)$ \\
\hline Warmth & 4.73 & 4.77 & .36 & .30 & -1.01 \\
Positive reinforcement & 4.73 & 4.68 & .44 & .43 & .78 \\
$\begin{array}{l}\text { Proactive parental } \\
\text { behaviour }\end{array}$ & 4.25 & 4.20 & .51 & .53 & .75 \\
$\begin{array}{l}\text { Permissiveness } \\
\text { Hostility }\end{array}$ & 2.13 & 2.14 & .65 & .65 & -.05 \\
Physical control & 2.41 & 2.37 & .60 & .57 & .56 \\
& 1.47 & 1.38 & .63 & .58 & .97
\end{tabular}

The differences is parents' assessment of children's temperament regarding gender are shown in Table 6. Similar to the assessment of parental behaviour, the results have shown that parents have equally assessed certain temperamental dimensions in boys and girls.

Table 6 A comparison of parents' assessment of children's temperament with respect to their gender ( $\mathrm{t}$-tests results)

\begin{tabular}{lccccc}
\hline & $\mathrm{M}_{\text {boys }}$ & $\mathrm{M}_{\text {girls }}$ & $\mathrm{SD}_{\text {boys }}$ & $\mathrm{SD}_{\text {girls }}$ & $\mathrm{t}(\mathrm{df}=192)$ \\
\hline Emotionality & 2.73 & 2.71 & .95 & .92 & .19 \\
Activity & 3.31 & 3.14 & .89 & .98 & 1.27 \\
Sociability & 3.59 & 3.55 & 1.23 & 1.20 & .21 \\
Impulsivity & 2.85 & 2.75 & .99 & .99 & .73 \\
\hline
\end{tabular}

In order to verify if there are differences in parents' assessment of developmental features of children regarding gender, t-tests were used which showed no differences, i.e. parents have equally rated the development of all areas regardless of the children's gender (Table 7). 
Table 7 A comparison of parents' assessment of developmental features with respect to their gender ( $t$-tests results)

\begin{tabular}{lccccc}
\hline & $\mathrm{M}_{\text {boys }}$ & $\mathrm{M}_{\text {girls }}$ & $\mathrm{SD}_{\text {boys }}$ & $\mathrm{SD}_{\text {girls }}$ & $\mathrm{t}(\mathrm{df}=192)$ \\
\hline Speech & 3.75 & 3.74 & 1.40 & 1.56 & .05 \\
Motor skills & 3.26 & 3.47 & 1.08 & 1.18 & $-1.32 \mathrm{I}$ \\
Independence & 3.77 & 3.78 & 1.44 & 1.53 & -.03 \\
Cognitive abilities & 3.50 & 3.59 & 1.39 & 1.45 & -.45 \\
Socio-emotional competence & 3.71 & 3.64 & 1.29 & 1.41 & .38 \\
Developmental difficulties & 2.23 & 2.34 & 1.38 & 1.47 & -.05 \\
\hline
\end{tabular}

Table 8 contains the correlation matrix which clearly shows that the temperamental activity dimension is closely linked to parental hostility as well as physical control. Therefore, parents who have rated their behaviours more hostile and use physical control more often, have also marked a higher level of activity as features of the child's temperament. Furthermore, speech development, development of fine motor skills, independence, cognitive abilities and socio-emotional competence are negatively linked to the emotionality dimension which leads to the conclusion that parents who have rated their children high on the emotionality dimension as temperamental features have also rated their developmental achievements in most areas lower. 


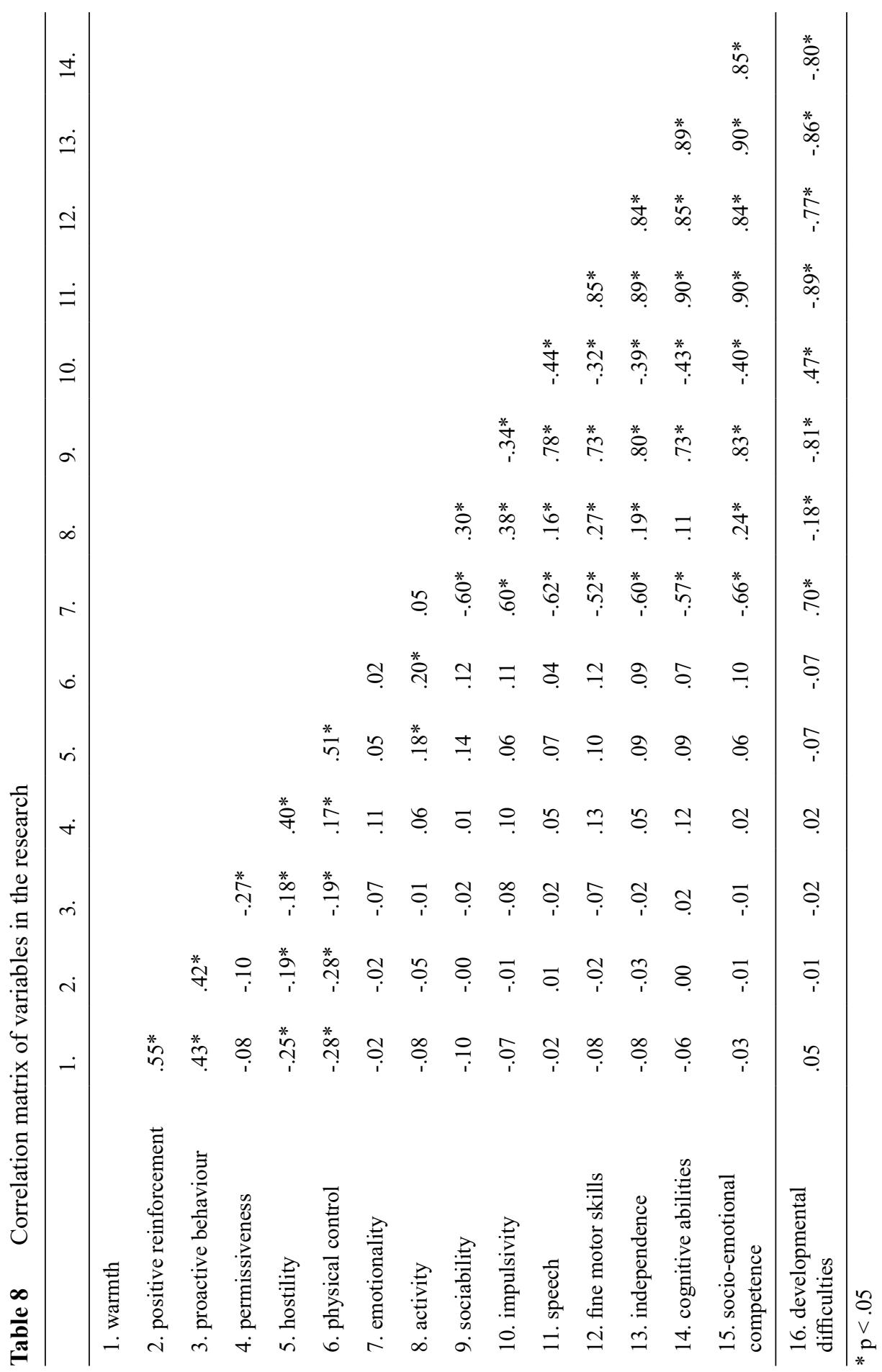


Table 9 shows the results of hierarchical regression analyses with developmental features as criteria and parental behaviours and children's temperament as predictor variables. The first block introduced temperamental variables which contributed significantly to the explanation of developmental outcomes of all areas assessed. Sociability proved to have the most important independent predictor potential for all developmental areas, while other temperamental dimensions proved significant for certain developmental areas. Therefore, emotionality is an important negative predictor for speech development, independence, social-emotional skills (i.e. a positive predictor for developmental difficulties). Activity is an important predictor only for fine motor skills development, while impulsivity, as a temperamental dimension, has significantly explained part of the speech development variance, variance of cognitive abilities and developmental difficulties. By introducing parental variables, in the second step of the analysis, there were no significant coefficient changes of multiple correlation which leads to the conclusion that parental behaviours do not explain the individual differences in developmental outcomes beyond temperament. The chosen predictors have explained a high $59 \%$ to $74 \%$ of criterion variance which can almost entirely be attributed to the dimension of the child's temperament, rated by their parents. 
T. Božiković, I. Reić Ercegovac, K. Kalebić Jakupčević, The Contribution of ...

Table 9 HRA results with developmental features of the child as criteria

\begin{tabular}{|c|c|c|c|c|c|c|}
\hline & Speech & $\begin{array}{l}\text { Motor } \\
\text { skills }\end{array}$ & Independence & $\begin{array}{l}\text { Cognitive } \\
\text { abilities }\end{array}$ & $\begin{array}{l}\text { Socio- } \\
\text { emotional } \\
\text { skills }\end{array}$ & Difficulties \\
\hline \multicolumn{7}{|c|}{$1^{\text {st }}$ step - temperament } \\
\hline Emotionality & $-.15^{*}$ & -.11 & $-.13 *$ & -.11 & $-.22 *$ & $.26^{*}$ \\
\hline Activity & .05 & $.15^{*}$ & .04 & .00 & .09 & -.08 \\
\hline Sociability & $.62^{*}$ & $.58 *$ & $.67^{*}$ & $.62 *$ & $.64 *$ & $-.58 *$ \\
\hline Impulsivity & $-.16^{*}$ & -.11 & -.11 & $-.15^{*}$ & -.08 & $.15^{*}$ \\
\hline $\mathrm{R}\left(\mathrm{R}^{2}\right)$ & $.81(.66)$ & $.75(.56)$ & $.81(.66)$ & $.76(.58)$ & $.86(.73)$ & $.86(.74)$ \\
\hline $\mathrm{F}(\mathrm{df})$ & $\begin{array}{l}91.46^{*} \\
(4,189)\end{array}$ & $\begin{array}{l}59.90^{*} \\
(4,189)\end{array}$ & $\begin{array}{l}91.75^{*} \\
(4,189)\end{array}$ & $\begin{array}{l}64.53^{*} \\
(4,189)\end{array}$ & $\begin{array}{l}130.0^{*} \\
(4,189)\end{array}$ & $\begin{array}{l}131.93^{*} \\
(4,189)\end{array}$ \\
\hline \multicolumn{7}{|c|}{$2^{\text {nd }}$ step - parental behaviours } \\
\hline Emotionality & $-.16^{*}$ & -.12 & $-.13 *$ & -.12 & $-.22 *$ & $.26^{*}$ \\
\hline Activity & .06 & $.16^{*}$ & .04 & .00 & $.10^{*}$ & -.08 \\
\hline Sociability & $.62 *$ & $.57 *$ & $.67 *$ & $.60 *$ & $.65^{*}$ & $-.58^{*}$ \\
\hline Impulsivity & $-.17 *$ & -.13 & -.11 & $-.16^{*}$ & -.09 & $.16^{*}$ \\
\hline Wormth & .04 & -.02 & -.01 & -.05 & .04 & .01 \\
\hline $\begin{array}{l}\text { Positive } \\
\text { reinforsement }\end{array}$ & .01 & .03 & -.01 & .01 & -.01 & -.02 \\
\hline $\begin{array}{l}\text { Proactive } \\
\text { behaviour }\end{array}$ & -.04 & -.04 & .00 & .07 & -.02 & .00 \\
\hline Permissiveness & .08 & $.16^{*}$ & .08 & $.18^{*}$ & .06 & -.02 \\
\hline Hostility & -.03 & -.10 & -.04 & -.05 & -.08 & .03 \\
\hline \multirow[t]{4}{*}{$\begin{array}{l}\text { Physical } \\
\text { control }\end{array}$} & -.02 & .06 & .02 & .02 & .05 & -.02 \\
\hline & $.82(.67)$ & $.77(.59)$ & $.82(.67)$ & $.78(.60)$ & $.86(.74)$ & $.86(.74)$ \\
\hline & .01 & .03 & .01 & .02 & .01 & .00 \\
\hline & $\begin{array}{c}36.97^{*} \\
(10,183)\end{array}$ & $\begin{array}{c}25.93^{*} \\
(10,183)\end{array}$ & $\begin{array}{c}36.47^{*} \\
(10,183)\end{array}$ & $\begin{array}{c}27.75^{*} \\
(10,183)\end{array}$ & $\begin{array}{c}52.39^{*} \\
(10,183)\end{array}$ & $\begin{array}{c}51.34 * \\
(10,183)\end{array}$ \\
\hline
\end{tabular}

$* \mathrm{p}<.05$ 


\section{DISCUSSION}

The main problem of this research was to examine the relationship between the dimensions of temperament, parental behaviour and developmental characteristics of the child and to determine whether the dimensions of parental behaviour and temperament of the child contribute to the developmental characteristics of the child. Before analyzing the main problem, the aim was to examine the relationship between parents' sociodemographic characteristics and their assessments of parental behaviour, as well as the existence of differences in parental behaviour, parental assessment of children's temperament and developmental characteristics with respect to the child's gender.

The results of the comparison of parents' assessments of temperamental characteristics of boys and girls did not show significant differences with respect to children's gender. These results deviate from expectations based on well-documented early gender differences in temperament indicated by the results of previous research. Namely, meta-analysis of gender differences in early temperament (Else-Quest et al., 2006) has clearly pointed to gender differences that are most evident in the dimensions of effortful control, surgency, and activity. The results of this research did not confirm these differences, which is probably due to different methodological aspects of the study. Namely, in this research, the child's temperament was assessed only by the parents through the instrument for assessing the dimensions of temperament according to the EASI model. In addition to the difference in the theoretical model, it should be noted that the method of assessment (by the parents) is very important in assessing the child's characteristics. Therefore, in future research, the assessments of educators or other professionals should be included, as suggested by other authors (Sindik \& Basta-Frljić, 2008; Tatalović Vorkapić \& Lončarević, 2015).

The results of the analysis of parental behaviours with respect to the child's gender showed that parental behaviours do not significantly differ when it comes to girls and boys. Therefore, parents assessed both positive (warmth, proactive parental behaviours, positive reinforcement) and negative (physical control, permissiveness, hostility) aspects of parental behaviours equally regardless of whether the child was a boy or a girl. Furthermore, parental comparisons in behaviours led to the conclusion that mothers and fathers differed in the warmth and proactive parental behaviour which mothers rated higher than fathers (i.e. in the permissiveness which was rated higher in fathers). No significant differences between mothers and fathers were found in the remaining three dimensions of parental behaviour. The result, which suggests that mothers are warmer than fathers and more prone to proactive parental behaviour, is in line with the expectations and results of previous research. For example, the research by Maglica et al. (2020) showed that mothers, compared to fathers, are more empathetic to pre-school aged children 
and are more understanding, which to some extent corresponds to the dimension of parental warmth. When it comes to permissiveness, it is possible that mothers, as they spend significantly more time interacting with preschool children than fathers (Altenburger et al., 2018), insist more on following rules and are less prone to a permissive approach. It is also possible that mothers in most families are, in a certain way, the ones who take on the role of setting boundaries and consequently are perceived as less permissive. During preschool age, fathers are usually more involved in activities related to play and engaging in various activities, so it is possible that the space for permissiveness towards setting and maintaining boundaries and rules of conduct is smaller for fathers than for mothers.

It should be noted that the results did not suggest a connection between the age or level of education of the parents nor any of the six dimensions of parental behaviour. Although it could have easily been expected that younger parents would show a higher level of permissiveness, due to lack of skills and higher levels of stress (Kušević, 2009) or that parents with a higher level of education would show a higher level of proactive parental behaviour due to greater motivation to develop pedagogical competence (Kesselring et al., 2012, according to Šimić \& Ljubetić, 2018), the obtained results may be a consequence of a relatively small variability in both of these socio-demographic variables.

Contrary to expectations, the results of the relationship between temperament dimensions and parental behaviour indicated a significant relation between the dimension of activity and two dimensions of parental behaviour-hostility and physical control. In other words, parents who have assessed a higher activity level of the child are also more likely to use physical control and show hostility toward the child. In all other combinations no significant association was found between the child's assessed temperament and parental behaviour. The result obtained regarding the connection between activity and hostility and physical control is not surprising since it is very probable that parents who assessed a high level of activity of the child (unable to sit, likes to run, restlessness, constant need to move) consider physical control appropriate in trying to regulate the child's behaviour. It is also possible that such high activity causes stress in parents to which they respond with hostility in the inability to respond more appropriately to the child's needs. The lack of connection between other dimensions of temperament and parental behaviours is not entirely consistent with parenting models which predict that a child's temperament is shaped to some extent by parental behaviours. For example, according to the model of determinants of parental behaviour (Belsky, 1984) in addition to parental characteristics, temperamental characteristics of the child represent a significant determinant of parental behaviour, similar to the integrative model of parenting proposed by Obradović and Čudina Obradović (2003). However, previous research has rarely examined the direct relationship between a child's temperament and parental behaviour, and much research in the field of 
parenting was focused on studying the consequences of parental behaviour on child adjustment, while fewer studies have addressed what causes certain parental behaviour (Macuka, 2010). In terms of temperament, it is important to note that most previous research on temperament included children of early and school age, in contrast to preschool (Sindik \& Basta-Frljić, 2008). The reason for the inconsistency of the obtained results may also arise from the meta-emotions of the assessor, in this case the parents, explains Brajša-Žganec (2002, according to Sindik \& Basta-Frljić, 2008), but it is also possible that participants chose socially desirable answers. Nevertheless, a child's behaviour that is assessed in only one situational set (at home) does not have to give a realistic insight into the child's behavioural style. Moreover, Tatalović Vorkapić and Lončarević (2015) emphasize that when assessing a child's temperament, it is more appropriate to take the assessment of preschool teachers, as opposed to the assessment of parents.

In assessing the relationship between children's temperamental characteristics and developmental outcomes, the results of this research showed a statistically significant connection between most variables. The table of intercorrelations (Table 8) shows that all developmental characteristics of the child except cognitive abilities (speech, fine motor skills, level of independence, cognitive and social-emotional skills) are statistically significantly positively associated with dimensions of sociability and activity, while these same developmental characteristics are statistically significantly negatively associated with the dimensions of emotionality and impulsivity. In addition, certain internalized and externalized difficulties proved to be statistically significantly positively associated with the dimensions of emotionality and impulsivity, while the remaining two dimensions of temperament proved to be statistically significantly negatively related. Macuka (2008) emphasizes that externalized disorders manifest as insufficiently controlled outward-directed behaviours, while internalized disorders manifest as internal reactions (fear, panic, anxiety, etc.). Similar to the results of this research, the research conducted by Sindik and Basta-Frljić (2007) shows the connection between developmental problems and three dimensions of temperament: impulsivity, emotionality and activity.

Contrary to expectations, the results of hierarchical regression analyses (Table 9) showed that parental behaviours do not significantly contribute to the explanation of individual differences in children's developmental characteristics beyond temperament dimensions. In other words, in addition to controlling the dimensions of a child's temperament, parental behaviours cannot explain individual differences in any of the developmental areas included in this research. Although not expected, the results should be seen in the context of the methodological limitations of the research as all assessments were performed only by parents. 


\section{CONCLUSION}

Before concluding, it is necessary to look at the shortcomings of the research which are related to the size and structure of the sample (i.e. to the fact that it is purposive and relatively small sample and that mostly mothers participated). Furthermore, all variables are the result of self-assessments and assessments of parents who were the only ones to assess both the dimensions of the children's temperament and their developmental outcomes, but their own parental behaviours as well. We would strongly recommend that future research include assessments of children by other adults (experts, educators) in order for these assessments to be more valid. Also, useful would be to involve educators in children's assessments given the fact that children manifest different behaviours in different situational settings, and to use multiple assessment sources which would give a more complete picture of the child's behaviour. Finally, it is worth emphasizing the somewhat lower reliability of individual subscales, especially the subscales of activities in the Temperament Questionnaire and the subscales of warmth, positive reinforcement, proactive behaviour and hostility from the Multidimensional Parenting Questionnaire. However, despite slightly lower subscale reliability coefficients, the results indicated satisfactory fit of the data to the six-factor model and was therefore used in the data analysis.

Despite the shortcomings, the results obtained by this research confirm the connection between child activity and two dimensions of parental behaviour-hostility and physical control, while other correlations did not show a significant relationship between individual dimensions of temperament and parental behaviour. When we look at the results of the assessment of the child's temperamental characteristics and developmental outcomes, a statistically significant correlation is seen between most variables, while parental behaviours do not contribute to the assessment of children's developmental characteristics with control of temperament, which in this research proved to be a major determinant of the developmental characteristics of preschool children. The results indicated the need to take into account the specifics of children's temperament when analysing the contribution of different parental behaviours to the developmental outcomes of preschool children.

\section{REFERENCES}

1. Altenburger, L. E., Schoppe-Sullivan, S. J., \& Kamp Dush, C. M. (2018). Associations between maternal gatekeeping and fathers' parenting quality. Journal of Child and Family Studies, 27, 2678-2689. DOI: 10.1007/s10826-018-1146-9

2. Bašić, J., Koller Trbović, N., \& Žižak, A. (2005). Integralna metoda u radu s predškolskom djecom i njihovim roditeljima - priručnik. Zagreb: Alinea.

3. Baumrind, D. (1967). Child care practices anteceding three patterns of preschool behaviour. Genetic Psychology Monographs, 75(1), 43-88.

4. Belsky, J. (1984). The determinants of parenting: A process model. Child Development, 55(1), 83-96. DOI: 10.2307/1129836

5. Berk, L. (2015). Dječja razvojna psihologija. Jastrebarsko: Naklada Slap. 
6. Berk, L. (2008). Psihologija cjeloživotnog razvoja. Jastrebarsko: Naklada Slap.

7. Brezinšćak, T., \& Roje, M. (2018). Emocionalni razvoj djeteta. In G. Buljan Flander et al. (Eds.), Znanost i umjetnost odgoja. Praktični priručnik o suvremenom odgoju za roditelje i odgajatelje (pp. 47-65). Sveta Nedelja: Naklada Geromar.

8. Buss, A. H., \& Plomin, R. (1975). A temperament theory of personality development. Wiley-Interscience.

9. Buss, A. H., \& Plomin, R. (1984). Theory and measurement of EAS. In A. H. Buss \& R. Plomin (Eds.), Temperament: Early developing personality traits (pp. 98-130). Erlbaum.

10. Buljan Flander, G., \& Ćorić Špoljar, R. (2018). Roditeljstvo nekad i danas. In G. Buljan Flander et al. (Eds.), Znanost i umjetnost odgoja. Praktični priručnik o suvremenom odgoju za roditelje i odgajatelje (pp. 21-31). Naklada Geromar.

11. Else-Quest, N. M., Shibley Hyde, J., Goldsmith, H., \& Van Hulle, C. A. (2006). Gender differences in temperament: A meta-analysis. Psychological Bulletin, 132(1), 33-72. DOI: 10.1037/0033-2909.132.1.33

12. Gravetter, F., \& Wallnau, L. (2014). Essentials of statistics for the behavioural sciences (8th ed.). Wadsworth.

13. Hui, C. H., \& Triandis, H. C. (1985). Measurement in cross-cultural psychology: a review and comparison of strategies. Journal of Cross-Cultural Psychology, 16, 131152. DOI: $10.1177 / 0022002185016002001$

14. Katz, L., \& McClellan, D. (2005). Poticanje razvoja dječje socijalne kompetencije. Educa.

15. Klarin, M. (2006). Razvoj djece u socijalnom kontekstu. Naklada Slap.

16. Kušević, B. (2009). Licencija za roditeljstvo - buduća realnost ili utopijska projekcija? Pedagogijska istraživanja, 6(1-2), 191-200.

17. Ljubetić, M. (2012). Nosi li dobre roditelje roda?! Profil International.

18. Ljubetić, M. (2011). Filozofija roditeljstva - obiteljsko ili društveno pitanje? Pedagogijska istraživanja, 8(2), 283-293.

19. Ljubetić, M., \& Batinica, V. (2015). Odnos kvalitete prošlog odnosa s ocem i nekih značajki rizičnog ponašanja kćeri (pilot-istraživanje). Napredak, 156(3), 253-266.

20. Ljubetić, M., Reić Ercegovac, I., \& Draganja, A. (2019). Razlike između odgojitelja i roditelja djece predškolske dobi u procjeni dječjih socio-emocionalnih kompetencija. Odgojno-obrazovne teme, 2(3-4), 185-204.

21. Macuka, I. (2010). Osobne i kontekstualne odrednice roditeljskog ponašanja. Suvremena psihologija, 13(1), 63-80.

22. Macuka, I. (2008). Uloga dječje percepcije roditeljskoga ponašanja u objašnjenju internaliziranih i eksternaliziranih problema. Društvena istraživanja, 17(6), 1179-1202.

23. Maglica, T., Reić Ercegovac, I., \& Ljubetić, M. (2020). Mindful parenting and behavioural problems in preschool children. Hrvatska revija za rehabilitacijska istraživanja, 56(1), 44-57.

24. Mathiesen, S. K., \& Tambs, K. (1999). The EAS temperament questionnaire-factor structure, age trends, reliability, and stability in a Norwegian sample. Journal of Child Psychology and Psychiatry, 3, 431-439. DOI:10.1111/1469-7610.00460

25. Obradović, J., \& Čudina-Obradović, M. (2003). Potpora roditeljstvu: izazovi i mogućnosti. Revija za socijalnu politiku, 10(1), 45-68. 
26. Parent, J., \& Forehand, R. (2017). The multidimensional assessment of parenting scale (MAPS): Development and psychometric properties. Journal of Child and Family Studies, 26, 2136-2151. DOI:10.1007/s10826-017-0741-5

27. Parent, J., McKee, L. G., Rough, J. N., \& Forehand, R. (2016). The association of parent mindfulness with parenting and youth psychopathology across three developmental stages. Journal of Abnormal Child Psychology, 44, 191-202. DOI: 10.1007/ s10802-015-9978-X

28. Pernar, M. (2010). Roditeljstvo. Medicina Fluminensis, 46(3), 255-260.

29. Reić Ercegovac, I., \& Ljubetić, M. (2019). Svjesnost u roditeljstvu majki i očeva djece različite dobi: Validacija hrvatske inačice upitnika. Psihologijske teme, 28(2), 397-418.

30. Rohner, R. P. (1986). New perspectives on family. The warmth dimension: Foundations of parental acceptance-rejection theory. Sage Publications, Inc.

31. Roje, M., \& Buljan Flander, G. (2018). Misaoni razvoj. In G. Buljan Flander et al. (Eds.), Znanost i umjetnost odgoja. Praktični priručnik o suvremenom odgoju za roditelje i odgajatelje (pp. 75-89). Naklada Geromar.

32. Rothbart, M. \& Derryberry, D.. (1981). Development of individual differences in temperament. In M. E. Lamb \& A. L. Brown (Eds.), Advances in Developmental Psychology, Vol. 1 (pp. 33-86). Earlbaum.

33. Rothbart, M. K., \& Putnam, S. (2002). Temperament and socialization. In L. Pulkkinen \& A. Caspi (Eds.), Paths to successful development: Personality in the life course (pp. 19-45). Cambridge University Press.

34. Sindik, J., \& Basta-Frljić, R. (2008). Povezanost karakteristika temperamenta i spremnosti djece za školu. Magistra iadertina, 3(1), 147-169.

35. Slunjski, E. (2012). Tragovima dječjih stopa. Profil International.

36. Slunjski, E. (2001). Integrirani predškolski kurikulum: rad djece na projektima. Mali profesor.

37. Starc, B., Čudina-Obradović, M., Letica, M., Profaca, B., \& Pleša, A. (2004). Osobine i psihološki uvjeti razvoja djeteta predškolske dobi. Golden marketing - Tehnička knjiga.

38. Šimić, K., \& Ljubetić, M. (2018). Razlike među roditeljima u percepciji pedagoške kompetencije. Učenje i nastava, 4(3), 437-458.

39. Štimac, D., \& Božić Knež, I. (2018). Motorički razvoj djeteta u ranoj dobi. In G. Buljan Flander et al. (Eds.), Znanost i umjetnost odgoja. Praktični priručnik o suvremenom odgoju za roditelje i odgajatelje (pp. 65-75). Naklada Geromar.

40. Tatalović Vorkapić, S., \& Lončarić, D. (2015). Measuring preschool children temperament: Implications for preschool care and education practice. International Journal of Educational Psychology, 4(3), 280-304. DOI:17583/ijep.2015.1483

41. Tatalović Vorkapić, S., \& Žagar, J. (2017). Is the evaluation of children's temperament independent from pre-school teachers' personality? The European Proceedings of Social \& Behavioural Sciences, XX, 84-96. Accessed: 19. 3. 2020.

42. Van de Vijver, F., \& Hambleton, R. K. (1996). Translating tests: Some practical guidelines. European Psychologist, 1(2), 89-99. DOI:10.1027/1016-9040.1.2.8

43. Vasta, R., Haith, M., \& Miller, S. (1997). Dječja psihologija. Naklada Slap. 